\title{
Caspase Inhibitor Diminishes Caffeic Acid-induced Apoptosis in Osteosarcoma Cells
}

\author{
Ferry Sandra ${ }^{1,2 *}$, Karina Febriani Hudono ${ }^{3}$, Amelia Astriani Putri ${ }^{3}$, Chantika Amardhia Paramita Putri ${ }^{3}$ \\ ${ }^{1}$ Department of Biochemistry and Molecular Biology, Division of Oral Biology, Faculty of Dentistry, Trisakti University, J1. Kyai Tapa No.260, \\ Jakarta, Indonesia \\ ${ }^{2}$ BioCORE Laboratory, Faculty of Dentistry, Trisakti University, Jl. Kyai Tapa No.260, Jakarta, Indonesia \\ ${ }^{3}$ Faculty of Dentistry, Trisakti University, J1. Kyai Tapa No.260, Jakarta, Indonesia \\ *Corresponding author. E-mail: ferrysandra@gmail.com
}

Received date:Jun 13, 2017; Revised date: Aug 2, 2017; Accepted date: Aug 3, 2017

\section{Abstract}

ACKGROUND: Caffeic acid has been shown to induce apoptosis in MG63 osteosarcoma cells. Along with the apoptotic induction, caffeic acid was shown to activate caspase- $8,-9$ and -3 . However, the role of caspase in mediating caffeic acid-induced apoptosis in MG63 cells are not clear yet. In this study, caspase role was further investigated by inhibiting caspase activity in the caffeic acid-induced apoptosis system in the MG63 cells.

METHODS: MG63 cells were cultured, starved, pretreated with/without Z-VAD FMK and treated with/without 10 $\mu \mathrm{g} / \mathrm{mL}$ caffeic acid. To quantify the number of apoptotic MG63 cells, Sub-G1 method was performed. The caffeic acid-induced apoptotic morphology was confirmed with 4',6-diamidino-2-phenylindole (DAPI) staining and Terminal deoxynucleotidyl transferase dUTP nick end labeling (TUNEL) assay. Meanwhile, to detect apoptotic underlying mechanism, immunoblotting was performed to detect caspase- $8,-9$ and -3 .
RESULTS: The MG63 cells were significantly induced into apoptosis with the treatment of $10 \mu \mathrm{g} / \mathrm{mL}$ caffeic acid for 48 hours. However, pretreatment of $100 \mu \mathrm{M}$ Z-VAD-FMK, a pan caspase inhibitor, for 2 hours, the percentage of apoptotic MG63 cells was significantly diminished. The apoptotic phenomenon induced by caffeic acid as well as the inhibition of Z-VAD-FMK were confirmed by DAPI staining and TUNEL assay. Cleaved caspase-8, -9 and -3 were formed markedly upon the treatment of caffeic acid. Pretreatment of 100 $\mu \mathrm{M}$ Z-VAD-FMK could inhibit the cleaved caspase-8, -9 and -3 .

CONCLUSION: Taken together, caffeic acid has the potential to induce apoptosis in MG63 cells, specifically through the caspase signaling pathway.

KEYWORDS: caffeic acid, apoptosis, MG63, caspase, Z-VAD FMK

Indones Biomed J. 2017; 9(3): 160-4

\section{Introduction}

Osteosarcoma is common in children or young adults. Osteosarcoma is reported to be the second highest cause of cancer-related deaths in this age group, mainly because of the frequent fatal metastases to the lungs.(1) Treatment using various chemotherapy regimens in the group of patients with different subtypes, did not significantly affect the survival of the patient. Therefore, new alternatives and other forms of therapy are needed.(1,2)

Various studies have been done to achieve the key to successful treatment of osteosarcoma. Approach through the mechanism of cancer cell apoptosis and the empowerment of natural materials to be one promising alternative, such as Ayamurasaki and Simon extract. $(3,4)$ Two varieties of sweet potato (Ipomoea batatas L.) are reported to contain caffeic acid compounds that proved to have the ability to inhibit 
osteoclastogenesis.(4-6) Caffeic acid significantly reduces the activity of nuclear factor $\kappa \mathrm{B}(\mathrm{NF \kappa B})$, a cell signaling pathway involved in osteoclastogenesis (5), in which NFкB inhibition can cause tumor cells to stop proliferating or becoming more sensitive to the actions of anti-tumor agents.(7)

Caffeic acid and related polyphenolic compounds today attract much special attention because of its ability to protect the human body from oxidative stress that can lead to cancer (8), aging (9), and cardiovascular disease (10). A previous study has shown that caffeic acid can induce apoptosis in MG63 osteosarcoma cells and show the presence of caspase- $8,-9$ and -3 in the induction of apoptosis.(11) However, the role of caspase in mediating caffeic acid-induced apoptosis in MG63 cells are not clear yet. Therefore, in this study, caspase role was further investigated by inhibiting caspase activity in the caffeic acid-induced apoptosis system in the MG63 cells.

\section{Methods}

\section{Cell Culture}

MG63 cells were cultured in Dulbecco's Modified Eagle Medium (Gibco, Grand Island, NY, USA), containing 10\% fetal bovine serum (Gibco) and antibiotic-antimycotic containing $200 \mathrm{units} / \mathrm{mL}$ penicillin, $200 \mu \mathrm{g} / \mathrm{mL}$ streptomycin and $0.5 \mu \mathrm{g} / \mathrm{mL}$ amphotericin (Gibco) in a humidified, $37^{\circ} \mathrm{C}$, 5\% CO2 incubator. Upon reaching $80 \%$ confluence, cells were sub-cultured.

\section{Sub-G1 Assay}

Sub-G1 assay of apoptotic cells was performed as described by Sandra, et al. $(12,13)$ Briefly, MG63 cells were treated with 0-10 $\mu \mathrm{g} / \mathrm{ml}$ caffeic acid (Wako, Osaka, Japan), harvested and suspended in $1 \mathrm{~mL}$ of hypotonic fluorochrome solution $(50 \mu \mathrm{g} / \mathrm{mL}$ propidium iodide in $0.1 \%$ sodium citrate plus $0.1 \%$ Triton X-100). Cell suspension was placed at $4{ }^{\circ} \mathrm{C}$ in the dark for 2 hours before the flow cytometric analysis. The propidium iodide fluorescence of individual nuclei was measured with a FACSCanto II flow cytometer (Becton Dickinson, Franklin Lakes, NJ, USA).

\section{4',6-diamidino-2-phenylindole (DAPI) Staining}

DAPI staining was performed as described by Sandra, et al.(14,15) Cells were seeded onto coverslips, stimulated, rinsed in phosphate buffered saline (PBS) and fixed with icecold tricholoroacetic acid and gradient ethanol. Then cells were permeabilized with $0.1 \%$ BSA and $0.1 \%$ Triton X-100 for 3 minutes, and stained with $1 \mu \mathrm{g} / \mathrm{ml}$ 4',6-Diamidino- 2-phenylindole (Calbiochem) for 3 minutes. Then, the coverslips were rinsed with PBS, mounted with glycerol on glass slides, and evaluated under fluorescence microscope.

\section{Terminal Deoxynucleotidyl Transferase dUTP Nick End Labeling (TUNEL) Assay}

This experiment was carried out using Apoptag Peroxidase In Situ Apoptosis Detection Kit (Chemicon, Temecula, CA). Briefly, cells were fixed with $1 \%$ paraformaldehyde in PBS (pH 7.4) and incubate in pre-cooled ethanol: acetic acid (2:1). Fixed cells were quenched in $3 \%$ hydrogen peroxide in PBS. Later, equilibration buffer was applied on the cells, followed by incubation of TdT enzyme in a humidified chamber for 1 hour. To stop the reaction, cells were washed with stop buffer and anti-digoxigenin peroxidase conjugate was applied on the cells in a humidified chamber for 30 minutes. For visualization, peroxidase substrate was applied and color development was monitored under microscope. Cells were later counterstained in methyl green. Negative control was done by replacing TdT enzyme with PBS, while positive control was provided along with the kit.

\section{Immunoblotting}

Immunoblotting was performed as described by Sandra, et al.(16,17) Treated cells were harvested and incubated with lysis buffer containing $20 \mathrm{mM}$ Tris buffer (pH 7.4), $5 \mathrm{mM}$ EDTA, $1 \%$ Triton-X, $50 \mathrm{mM}$ sodium fluoride, $2 \mathrm{mM}$ sodium orthovanadate, $10 \mathrm{mM}$ sodium pyrophosphate, $1 \mathrm{mM}$ p-amidinophenyl methanesulfonyl fluoride hydrochloride and protease inhibitor cocktail (Sigma, St. Louis, MO, USA). Samples were separated by SDS-polyacrylamide gel electrophoresis and transferred to a pure nitrocellulose membrane. After blocking with 5\% skim milk in phosphate buffer saline $(\mathrm{pH} 7.4)$, the sheets were probed with the following 1:1000 diluted antibodies: mouse monoclonal anticleaved caspase-8 (Asp384) (Cell Signaling, Beverly, MA, USA), rabbit polyclonal anti-cleaved caspase-9 (Asp315) (Cell Signaling) and rabbit polyclonal anti-cleaved caspase-3 (Asp175) (Cell Signaling). The secondary antibody was 1:1000 diluted horseradish peroxidase-conjugated donkey anti-rabbit (Amersham, Buckinghamshire, UK) or 1:2000 diluted horseradish peroxidase-conjugated sheep antimouse (Amersham) antibody. The bound antibodies were visualized using Immun Star HRP Chemiluminescent Kit (BioRad, Hercules, CA, USA). All visualized bands were captured using Alliance 4.7 (UVItech, Cambridge, UK).

\section{Statistical Analysis}

Shapiro Wilk test was performed to determine distribution of apoptosis with Sub-G1 assay. Independent samples 
$\mathrm{T}$ test was performed to compare apoptosis pretreated with/without Z-VAD-FMK and treated with caffeic acid and. Statistical analysis was performed using IBM SPSS Statistics for Macintosh ver. 21 (SPSS IBM, Armonk, NY, USA). Statistically significance was expressed as $p<0.05$.

\section{Results}

\section{Caspase Inhibitor Diminished Caffeic Acid-induced} Apoptotic Cells

MG63 cells were significantly $(p=0.000)$ induced into apoptosis with the treatment of $10 \mu \mathrm{g} / \mathrm{mL}$ caffeic acid for 48 hours (Figure 1). However, pretreatment of 100 $\mu \mathrm{M}$ Z-VAD-FMK, a pan caspase inhibitor, for 2 hours, the percentage of apoptotic MG63 cells was significantly $(p=0.000)$ diminished.

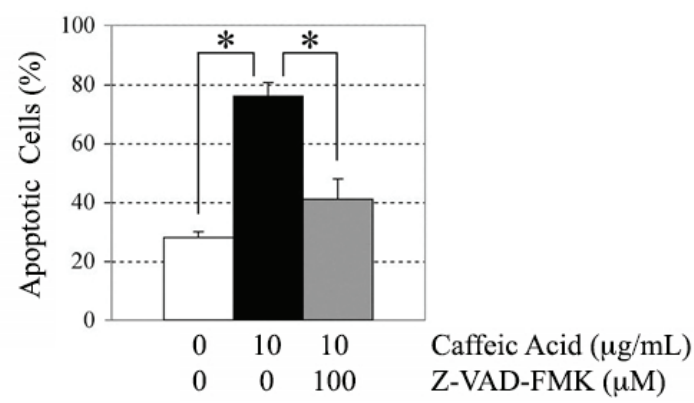

Figure 1. Caspase inhibitor diminished caffeic acid-induced apoptotic cells. MG63 cells were starved for 12 hours, pretreated with/without $100 \mu \mathrm{MZ}$-VAD FMK for 2 hours, before addition of $10 \mu \mathrm{g} / \mathrm{mL}$ caffeic acid for 48 hours. Then cells were processed for Sub-G1 assay. These experiments were repeated 3 times. Results were statistically analyzed with Independent $\mathrm{T}$ test. ${ }^{*} p<0.05$.

\section{Caspase Inhibitor Diminished Caffeic Acid-induced Nuclear Fragmentation}

With DAPI staining, treatment of $10 \mu \mathrm{g} / \mathrm{mL}$ caffeic acid for 48 hours clearly showed nuclear fragmentation in MG63 cells (Figure 2). Meanwhile, pretreatment of 100 $\mu \mathrm{M}$ Z-VAD-FMK for 2 hours, the nuclear fragmentation in MG63 cells was abolished.

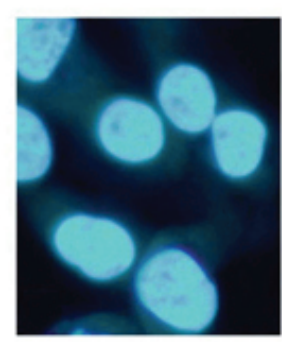

0

0

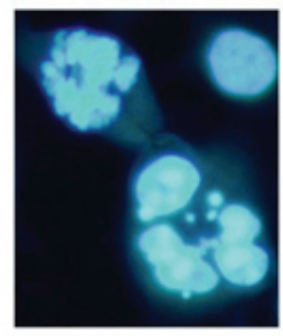

10

0

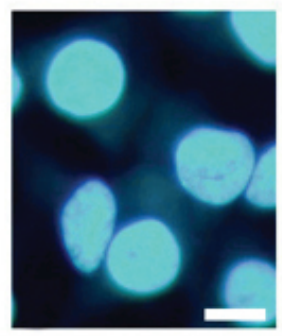

10

100
Cafeic Acid $(\mu \mathrm{g} / \mathrm{mL})$

Z-VAD-FMK $(\mu \mathrm{M})$
Figure 2. Caspase inhibitor diminished caffeic acid-induced nuclear fragmentation. MG63 cells were starved for 12 hours, pretreated with/without $100 \mu \mathrm{M}$ Z-VAD FMK for 2 hours, before addition of 10 $\mu \mathrm{g} / \mathrm{mL}$ caffeic acid for 48 hours. Then cells were processed for DAPI staining. These experiments were repeated 3 times. 


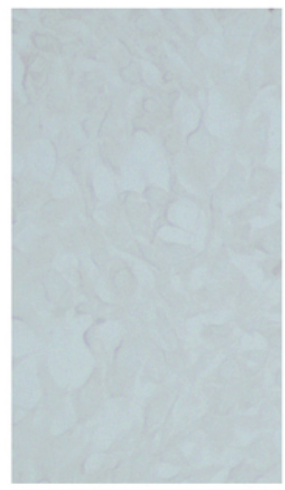

0

0

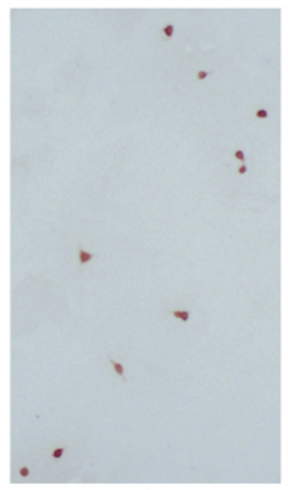

10

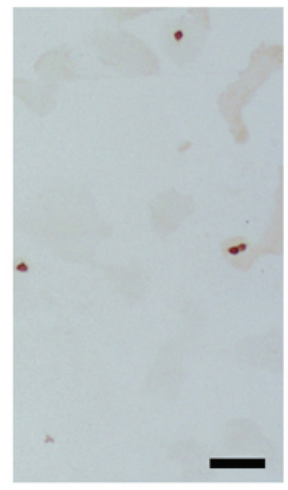

10

100
Cafeic Acid $(\mu \mathrm{g} / \mathrm{mL})$

Z-VAD-FMK $(\mu \mathrm{M})$
Figure 3. Caspase inhibitor diminished caffeic acidinduced DNA fragmentation. MG63 cells were starved for 12 hours, pretreated with/without $100 \mu \mathrm{M} Z$ Z-VAD FMK for 2 hours, before addition of $10 \mu \mathrm{g} / \mathrm{mL}$ caffeic acid for 48 hours. Then cells were processed for TUNEL assay. These experiments were repeated 3 times. into apoptosis. This phenomenon was confirmed by DAPI staining as well as TUNEL assay.

The involvement of the caspase signaling pathway was also shown in previous studies using natural Indonesian plants, including Brucea javanica $(17,18)$ and Artocarpus heterophyllus $(19,20)$. Both of these natural plants are reported to decrease expression of pro-caspase-3. In present study, the pretreatment of Z-VAD FMK, a pan caspase inhibitor, caused a decrease of apoptotic cell number. Accordingly cleaved or activated Caspase- $8,-9$ and -3 by caffeic acid were markedly diminished by Z-VAD FMK. However, although it has been shown that caffeic acid can induce apoptosis in MG63 cells through the caspase signaling pathway, there are also possibility of alternative pathways or caspase-independent pathway.

The results of this study are expected to be the basis for the development of pharmacological design of a new generation of drugs for osteosarcoma. However,

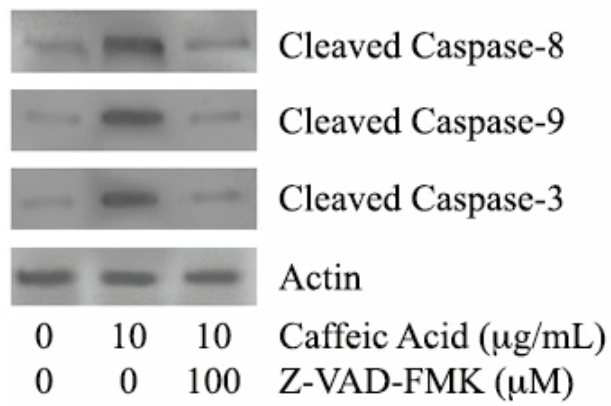

Figure 4. Caspase inhibitor diminished caffeic acid-induced activation of Caspase-8, $\mathbf{- 9}$ and $\mathbf{- 3}$. MG63 cells were starved for 12 hours, pretreated with/without $100 \mu \mathrm{M}$ Z-VAD FMK for 2 hours, before addition of $10 \mu \mathrm{g} / \mathrm{mL}$ caffeic acid for 48 hours. Cells were collected, lysed and processed further for immunoblotting detection by using anti-cleaved caspase- $8,-9$ and -3 antibodies. These experiments were repeated 3 times. the complexity of apoptotic mechanisms requires further investigation, particularly to determine the caspaseindependent pathway involved in the process of MG63 cell apoptosis by caffeic acid and its effect on other osteosarcoma cell types. Taken together, caffeic acid has the potential to induce apoptosis in MG63 cells, specifically through the caspase signaling pathway.

\section{References}

1. Ta HT, Dass CR, Choong PF, Dunstan DE. Osteosarcoma treatment: state of the art. Cancer Metastasis Rev. 2009; 28: 247-63.

2. Grohar PJ, Helman LJ. Prospects and challenges for the development of new therapies for Ewing sarcoma. Pharmacol Ther. 2013; 137: 216-24.

3. Tanaka M, Ishiguro K, Oki T, Okuno S. Functional components in sweetpotato and their genetic improvement. Breed Sci. 2017; 67: 52-61.

4. Tang QY, Kukita T, Ushijima Y, Kukita A, Nagata K, Sandra F, et al. Regulation of osteoclastogenesis by Simon extracts composed of caffeic acid and related compounds: successful suppression of bone destruction accompanied with adjuvant-induced arthritis in rats. Histochem Cell Biol. 2006; 125: 215-25.

5. Sandra F, Kukita T, Tang QY, Iijima T. Caffeic acid inhibits NFkappaB activation of osteoclastogenesis signaling pathway. Indones Biomed J. 2011; 3(3): 216-22.

6. Sandra F, Kukita T, Muta T, Iijima T. Caffeic acid inhibited receptor activator of nuclear factor $\mathrm{\kappa B}$ ligand (RANKL)-tumor necrosis factor (TNF) $\alpha$-TNF receptor associated factor (TRAF) 6 induced osteoclastogenesis pathway. Indones Biomed J. 2013; 5(3): 173-8.

7. Kannaiyan R, Hay HS, Rajendran P, Li F, Shanmugam MK, Vali S, et al. Celastrol inhibits proliferation and induces chemosensitization through down-regulation of NF- $\mathrm{KB}$ and STAT3 regulated gene products in multiple myeloma cells. Br J Pharmacol. 2011; 164 1506-21.

8. Dziedzic A, Kubina R, Kabała-Dzik A, Tanasiewicz M. Induction of cell cycle arrest and apoptotic response of head and neck squamous carcinoma cells (Detroit 562) b y 
caffeic acid and caffeic acid phenethyl ester derivative. Evid Based Complement Alternat Med. 2017; 2017: 6793456. doi: 10.1155/2017/6793456.

9. Spagnol CM, Di Filippo LD, Isaac VLB, Corrêa MA, Salgado HRN. Caffeic acid in dermatological formulations: in vitro release profile and skin absorption. Comb Chem High Throughput Screen. 2017. doi: 10.2174/1386207320666170602090448.

10. Bertelli AA. Wine, research and cardiovascular disease: instructions for use. Atherosclerosis. 2007; 195: 242-7.

11. Sandra F, Sidharta MA. Caffeic acid induced apoptosis in MG63 osteosarcoma cells through activation of caspases. Mol Cell Biomed Sci. 2017; 1: 28-33.

12. Sandra F, Khosravi-Far R. Survivin S81A enhanced TRAIL's activity in inducing apoptosis. Indones Biomed J. 2010; 2: 113-7.

13. Sandra F, Sudiono J, Sidharta EA, Sunata EP, Sungkono DJ, Dirgantara $\mathrm{Y}$, et al. Conditioned media of human umbilical cord blood mesenchymal stem cell-derived secretome induced apoptosis and inhibited growth of HeLa cells. Indones Biomed J. 2014; 6(1): 57-62.

14. Sandra F, Hendarmin L, Nakao Y, Nakamura N, Nakamura S. Inhibition of Akt and MAPK pathways elevated potential of TNFalpha in inducing apoptosis in ameloblastoma. Oral Oncol. 2006; 42: 39-45
15. Sandra F, Oktaviono YH, Widodo MA, Dirgantara Y, Chouw A, Sargowo D. Endothelial progenitor cells proliferated via MEKdependent p42 MAPK signaling pathway. Mol Cell Biochem. 2015; 400: 201-6.

16. Sandra F, Hendarmin L, Nakao Y, Nakamura N, Nakamura S. TRAIL cleaves caspase-8, -9 and -3 of AM-1 cells: a possible pathway for TRAIL to induce apoptosis in ameloblastoma. Tumor Biol. 2005; 26: 258-64.

17. Rizal MI, Sandra F. Brucea javanica leaf extract activates caspase- 9 and caspase-3 of mitochondrial apoptotic pathway in human oral squamous cell carcinoma. Indones Biomed J. 2016; 8: 43-8.

18. Wicaksono BD Tangkearung E, Sandra F. Brucea javanica leaf extract induced apoptosis in human oral squamous cell carcinoma (HSC2) cells by attenuation of mitochondrial membrane permeability. Indones Biomed J. 2015; 7: 107-10.

19. Arung ET, Wicaksono BD, Handoko YA, Kusuma IW, Shimizu K, Yulia D, et al. Cytotoxic effect of artocarpin on T47D cells. J Nat Med. 2010; 64: 423-9.

20. Arung ET, Wicaksono BD, Handoko YA, Kusuma IW, Yulia D, Sandra F. Anti-cancer properties of diethylether extract of wood from Sukun (Artocarpus altilis) in human breast cancer (T47D) cells. Trop J Pharm Res. 2009; 8: 317-24. 